\title{
Intravascular fasciitis of the breast
}

\section{Memede intravasküler fasiit}

\author{
Ömer Eronat ${ }^{1}$, Mehmet Doğan², Niyazi Karaman ${ }^{3}$, Olcay Kandemir ${ }^{2}$
}

${ }^{1}$ Özel Synevo Laboratuvarları, T1bbi Patoloji Bölümü, Ankara, Türkiye

${ }^{2}$ Dr. Abdurrahman Yurtaslan Onkoloji Eğitim ve Araştırma Hastanesi, Tıbbi Patoloji Kliniği, Ankara, Türkiye

${ }^{3}$ Dr. Abdurrahman Yurtaslan Onkoloji Eğitim ve Araştırma Hastanesi, Genel Cerrahi Kliniği, Ankara, Türkiye

Dergiye Ulaşma Tarihi: 11.12.2017 Dergiye Kabul Tarihi: 02.01.2018 Doi: 10.5505/aot.2018.54366

\section{ÖZET}

İntravasküler fasiit küçük ve orta çaplı damarların duvar ve lümenlerini tutan, reaktif myofibroblastik hücre proliferasyonudur. Nodüler fasiitin daha nadir görülen bir varyantıdır. Benign bir lezyon olmasına rağmen sıklıkla malign tümörler ile karışabilmektedir. Bu olgu sunumunda 54 yaşında bir bayan hastanın sağ memesinden eksize edilen lumpektomi spesimeninde intravasküler fasiit olgusu sunulmuştur.

Anahtar Kelimeler: İntravasküler fasiit, nodüler fasiit, meme

\section{ABSTRACT}

Intravascular fasciitis is a reactive myofibroblastic proliferation that involves wall and lumen of small to medium-sized vessels. It is a rare variant of nodular fasciitis. Although its benign nature, it can be often confound with malignant tumors. In this report we present a case of intravascular fasciitis from a 54 year old female patients lumpectomy removed from the right breast.

Keywords: Intravascular fasciitis, nodular fasciitis, breast

\section{GíRiş}

İntravasküler fasiit küçük ve orta çaplı arter ve venlerin duvar ile lümenlerini tutan reaktif myofibroblastik bir proliferasyondur (1). Her yaşta görülebilse de en sık 3. dekadda ve daha çok erkeklerde görülür (2). Nodüler fasiitin daha nadir görülen bir varyantı olan intravasküler fasiit, malign tümörler ile karışabilmesinden dolayı klinik ve patolojik açıdan önem kazanmaktadır. Klinikte en s1k karşılaşılan lokalizasyonlar üst ekstremiteler ile baş ve boyun bölgeleridir. Meme ise intravasküler fasiitin son derece nadir görüldügü bir organdır (3). $\mathrm{Bu}$ olgu sunumunda 54 yaşında bayan hastanın sağ memesinden eksize edilen lumpektomi spesimeninde intravasküler fasiit olgusu sunulmuştur.

\section{OLGU SUNUMU}

54 yaşında bayan hasta Ankara Doktor Abdurrahman Yurtaslan Onkoloji Hastanesi Genel Cerrahi Polikliniğine, yaklaşık bir aydır eline gelen sağ memede kitle şikâyeti ile başvurdu. Hastanın anamnezinde travma öyküsü bulunmuyordu. Yapılan dinamik ve diffüzyon MRG değerlendirmesinde sağ memede ciltten $1 \mathrm{~cm}$ derinde, $0,7 \times 0,5 \mathrm{~cm}$ boyutlarında BI_RADS 4A olarak siniflanan solid kitle lezyon saptand ve eksizyonu önerildi. Hastanın rutin laboratuvar tetkiklerinde özellik izlenmedi.

Hastanın onamı alındıktan sonra genel cerrahi tarafindan genel anestezi altında telle işaretli kitle cilt dokusu ile birlikte eksize edildi. Patoloji laboratuvarı tarafindan kabulü yapılan lumpektomi spesimeninin makroskobik incelemesinde, üzerinde $1,8 \times 0,5$ $\mathrm{cm}$ ölçülerinde deri bulunan telle işaretli $3,8 \times 3 \times 1 \mathrm{~cm}$ ölçülerinde meme dokusu izlendi. 
Doku dilimlendiğinde $2 \times 1,5 \mathrm{~cm}$ ölçülerinde krem renkli meme dokusunda, en geniş çap1 $0,7 \mathrm{~cm}$ olan düzgün sınırlı, hafif sert, kirli beyaz renkli odak dikkati çekti. Tariflenen lezyonun tümü örneklendi.

Örneklenen dokulardan hazırlanan hematoksilen ve eozin ile boyalı preparatların mikroskobik incelemesinde, adenozisle karakterize fibrotik meme dokusuna komşu fibrolipomatöz dokuda iyi sınırlı, bir ucunda orta çaplı kalın duvarlı bir damar yapısı ile devamlı görünümde yumuşak doku lezyonu izlenmekteydi (Resim 1). Mevcut lezyon, damarın kas tabakası içinde prolifere olan iğsi hücrelerden meydana gelmekte olup mitotik aktivite göstermekteydi (Resim 2). Lezyonun çevresi iyi sınırlıydı ve cerrahi sınırlarda devam etmemekteydi.

Yapılan immünhistokimyasal çalışmalarda iğsi hücrelerde SMA (düz kas aktini) ile reaksiyon izlenirken (pozitif), Desmin, PanCK (pansitokeratin), beta catenin, CD34 ve S100 ile reaksiyon saptanmad1 (negatif). Ki-67 proliferasyon indeksi \%3-4 olarak gözlendi (Resim 3,4 ve 5).

Postoperatif dönemde herhangi bir komplikasyon gelişmedi ve hasta ertesi gün taburcu edildi.

\section{TARTIŞMA}

İntravasküler fasiit, intramüsküler fasiit ile birlikte nodüler fasiitin alt tiplerindendir. Klasik nodüler fasiite göre daha yavaş büyür ancak biyolojik davranışları aynıdır. İntravasküler fasiit küçük ve orta çaplı arter ve venlerin duvar ile lümenlerini tutan reaktif myofibroblastik hücre proliferasyondur. İlk üç dekadda daha sık görülse de her yaşta ortaya çıkabilir. Klinikte en sık karşılaşılan lokalizasyonlar üst ekstremiteler ile baş ve boyun bölgeleridir. Alt ekstremitelerde ve gövdede daha nadir rastlanır.

İntravasküler fasiit tanısı eksizyon materyalin histopatolojik incelemesiyle konulmaktadır. Tıpkı nodüler fasiite olduğu gibi intravasküler fasiit ödemli miksoid bir stromada iğsi, kaba nükleuslu atipi içermeyen, artmış mitotik aktivite ile karakterize hücrelerden meydana gelmektedir. Lezyona sıklıkla lenfositler, makrofajlar ve ekstravaze eritrositlerle osteoklast benzeri dev hücreler eşlik edebilmektedir (4). İmmünhistokimyasal olarak myofibroblastik hücreler SMA, vimentin ve calponin ile pozitifken S100, desmin, keratin, CD34, caldesmon ve ALK ile negatiftir $(2,5,6)$.

Klinik olarak genellikle ağrısız kitle lezyon şeklinde prezante olur. Tedavisi konservatif cerrahi eksizyondan ibaret olup (2), lezyonun totali eksize edilmediğinde dahi son derece nadir nüks eder. Yine de hastalığın nüksü söz konusuysa patolojik tanıyı gözden geçirmekte yarar vardır. Hastalığın uzak organ metastazı yaptığına dair bir bilgi mevcut değildir.

Psödosarkoma olarak da adlandırılan intravasküler fasiit, reaktif myofibroblastik bir proliferasyon olmasına karşın artmış mitotik aktivitesinden, sellüler ve hizlı büyüyen bir lezyon olmasından dolayı yanlışlıkla sarkomlar ile karışabilir. Hiperkromatik atipik nükleusların, atipik mitotik figürlerin yokluğu sarkomlardan ayırımda akılda bulundurulmas1 gereken hususlardır (7). Gerçekte benign karakterde olan ancak malign neoplaziler ile karışabilecek lezyonların doğru tanı almaları ve hastaların uygun bir şekilde tedavi edilmeleri son derece önemlidir. Bu olguda sunduğumuz gibi hastanın memesinde beliren kitlenin kısa sürede büyümüş olması ve radyolojik görüntüleme yöntemlerinde şüpheli lezyon grubunda değerlendirilmesi olası bir malignite ihtimalini de beraberinde getirmiştir. İntravasküler fasiitin etyolojisi bilinmemekle birlikte olguların \%10'unda travma öyküsü mevcuttur $(1,8)$. Literatürde organize trombüslere sekonder geliştiğine dair olgular $(1,8,9)$ ile gebe kadınlarda östrojen hormonuyla ilişkili olabileceğini gösteren olgular bildirilmiş (10). Ancak bu ilişkileri ortaya koyan vakalar sayıca az olmakla birlikte bu konuda daha fazla çalışmalara ihtiyaç duyulmaktadir.

İntravasküler fasiit için nodüler fasiitin bir varyantı olup damarlar ile ilişkilidir. $\mathrm{Bu}$ olgu ile, neoplastik olmayan bu lezyon hakkındaki farkındalığı arttırmak ve olası yanlış tanılara engel olabilmek adına katkı sağlamayı amaçladık.

\section{Conflict of interest: None}




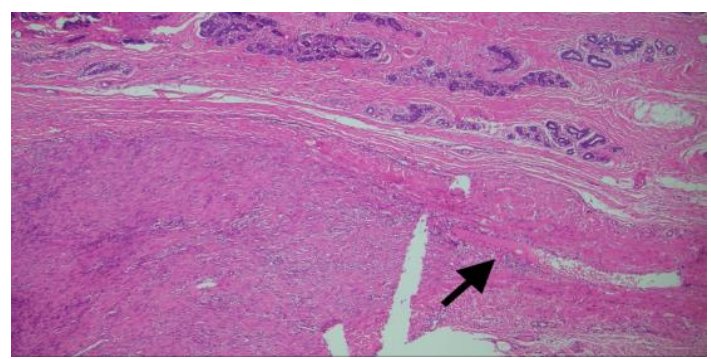

Resim 1. Meme dokusundan iyi sınırla ayrılmış, orta çaplı damar (siyah ok) trasesini takip eden myofibroblastik hücre proliferasyonu (HE X40).

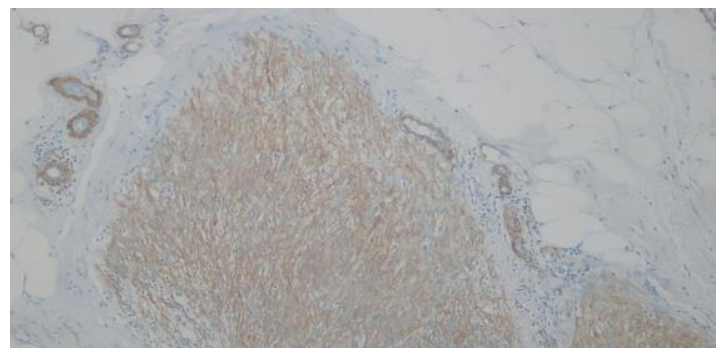

Resim 3. Myofibroblastik hücrelerde SMA pozitifliği (X100)

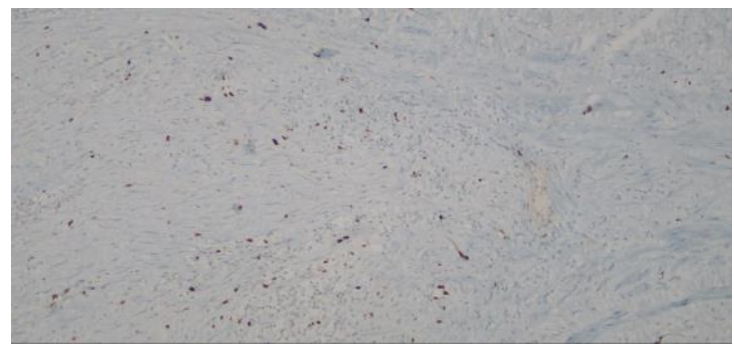

Resim 5. Ki67 proliferasyon indeksi (X100)

\section{REFERANSLAR}

1. Patchefsky AS, Enzinger FM. Intravascular fasciitis: A report of 17 cases. Am J Surg Pathol. 1981;5(1).

2. Chi AC, Dunlap WS, Richardson MS, Neville BW. Intravascular Fasciitis: Report of an Intraoral Case and Review of the Literature. Head Neck Pathol. 2012;6(1):140-5.

3. Brown V, Carty NJ. A case of nodular fascitis of the breast and review of the literature. The Breast. 2017;14(5):384-7.

4. Wang L, Wang G, Wang L, Gao T. Myxoid intravascular fasciitis. J Cutan Pathol. 2011;38(1):63-6.

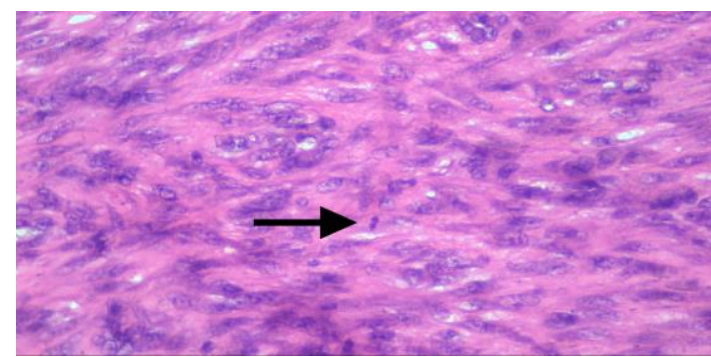

Resim 2. Hafif atipi ile karakterize iğsi miyofibroblastik hücrelerde mitotik aktivite (siyah ok) (HE X400).

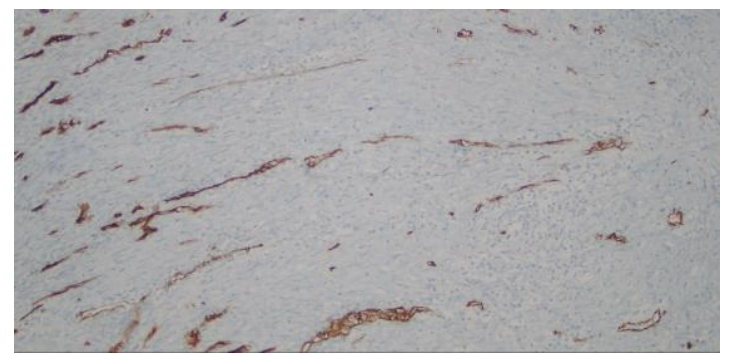

Resim 4. Myofibroblastik hücreler CD34 negatiftir (X100)

Adress for correspondence: Özel Synevo Lab. Ceyhun Atıf Kansu Cad. 135/a Balgat 06520 Ankara - Türkiye e-mail: eronatomer@gmail.com

Available at www.actaoncologicaturcica.com

Copyright $\odot$ Ankara Onkoloji Hastanesi

5. Kayaselçuk F, Demirhan B, Kayaselçuk U, Özerdem ÖR, Tuncer I. Vimentin, smooth muscle actin, desmin, S-100 protein, p53, and estrogen receptor expression in elastofibroma and nodular fasciitis. Ann Diagn Pathol. 2002;6(2):94-9.

6. Perez-Montiel MD, Plaza JA, DominguezMalagon H, Suster S. Differential Expression of Smooth Muscle Myosin, Smooth Muscle Actin, $\mathrm{H}$-Caldesmon, and Calponin in the Diagnosis of Myofibroblastic and Smooth Muscle Lesions of Skin and Soft Tissue. Am J Dermatopathol. 2006;28(2) 
7. Rosenberg AE. Pseudosarcomas of Soft Tissue. Arch Pathol Lab Med. 2008;132(4):579-86.

8. Price SK, Kahn LB SN. Dermal and intravascular fasciitis. Unusual variants of nodular fasciitis. Am J Dermatopathol. 1993;15(6):539-543.
9. Sugaya M TK. Does thrombosis cause intravascular fasciitis? Acta Derm Venereol. 2007;87(4):369-70.

10. Anand A, Tsapakis EM, Narvani AA, Alhakim A, Cannon SR, Tsiridis E. "Pseudosarcoma" in a pregnant woman. World J Surg Oncol. 2007;5:7. 